\title{
Prospects of Plant-Based Systems as an Eco- Technological Approach for Heavy Metals Removal from Polluted-Waters
}

\author{
Leonardo Martín Pérez ${ }^{1,2,3 *}$ \\ ${ }^{1}$ Grupo de Biotecnología de Materiales y Medioambiente (Bio\&TecMA, UCA-CONICET), Instituto de Investigaciones en Ingeniería Ambiental, Química y \\ Biotecnología Aplicada (INGEBIO-UCA), Facultad de Química e Ingeniería del Rosario, Pontificia Universidad Católica Argentina (UCA), Av. Pellegrini \\ 3314, S2002QEO Rosario (Santa Fe), Argentina \\ ${ }^{2}$ Consejo Nacional de Investigaciones Científicas y Técnicas (CONICET), Ministerio de Ciencia, Tecnología e Innovación, Godoy Cruz 2290, C1425FQB \\ CABA (Buenos Aires), Argentina \\ ${ }^{3}$ UNESCOSOST-Argentina, UNESCO Chair on Sustainability-Universitat Politècnica de Catalunya (UPC-BarcelonaTech), C/Colom, 1, TR1, ESEIAAT, \\ 08222 Terrassa, Spain
}

Submission: January 04, 2021; Published: April 01, 2021

Corresponding author: Leonardo Martín Pérez, Instituto de Investigaciones en Ingeniería Ambiental, Química y Biotecnología Aplicada (INGEBIO-UCA), Facultad de Química e Ingeniería del Rosario, Pontificia Universidad Católica Argentina (UCA), Av Pellegrini 3314, S2002QEO Rosario (Santa Fe), Argentina

\section{Mini Review}

Contamination of natural waters by the release of aqueous effluents containing organic and inorganic poisoning substances, mostly from agro-industrial origin, has been hard increased since the beginning of the 21st century. In the last decades, environmental contamination with heavy metals has turned to a worldwide problem due to the fast growing of industrialization and urbanization. Metals are major pollutants of fresh-water reservoirs because of their non-biodegradability and highpersistence in nature. In addition, some metals are highly toxic even at very low concentrations [1]. Heavy metals are not only a serious threat to the environment but also to all living beings, including humans, since all metallic ions are inert to chemical and biological degradation and can be transferred through the trophic chain [2].

Metal's poisoning has been recognized as a major public health concern, particularly in developing and poor countries where sanitary issues are wicked, and solutions are scarce. For example, arsenic (As), cadmium (Cd), mercury ( $\mathrm{Hg}$ ), and lead ( $\mathrm{Pb}$ ) are toxic metals of high environmental importance currently included by the World Health Organization in the list of the ten chemicals of major public risk [3]. Although heavy metals toxicity is a highly explored matter, complete control and prevention over metals exposure is still far from being attained. Therefore, the search for new technologies, preferably clean and inexpensive ones, that can be used to remove heavy metals from the environment is still desired.

Conventional wastewater treatment technologies for heavy metals elimination are usually expensive and somewhat inefficient. Chemical flocculation/precipitation, ion exchange, electrochemical deposition and membrane filtration are some of the methods typically applied for heavy metals removal from industrial effluents. However, much of such processes are restricted due to technical or economical limitations, specially to remediate large volumes of polluted waters [1]. In such sense, the use of vascular plants for the removal of heavy metals from wastewater and industrial effluents (i.e., phytoremediation) have been proved to be an eco-friendly and sustainable biotechnology [4-6]. Moreover, in high-flow treatment systems, the use of freefloating macrophytes have been shown to be satisfactory.

One of its major advantages is that plants can be used as low-cost extract pumps to purify contaminated water, thus being an appropriate solution to remediate large areas or to complete decontamination in longer periods of time. In general, phytoremediation technology can be explained on plants ability to adsorb, accumulate, sequestrate and/or tolerate high concentrations of metals in plants roots or leaves. Its success depends on the physicochemical properties of the plants utilized, and some other genetic and biological features such as high biomass productivity, geographical distribution, climate adaptation, and tolerance to toxic metals $[7,8]$.

For a plant-based wastewater treatment system to be feasible and sustainable, it is essential that plants used are not only efficient in heavy metals removal, but also highly abundant at the region, easily accessible, and do not require special culture conditions in order to minimize costs. Plant-based technologies have been shown to be highly competitive for heavy metals elimination compared to the classical Physico-chemical methods. In general, 
metal sorption by the plants roots is the fastest component of the metal uptake mechanism and may occur by a combination of physical and chemical processes such as ionic bonds, chemical chelation, and ionic exchange.

The content of macromolecules such as polysaccharides, lipids, and proteins with negatively charged groups (e.g., carboxyl, sulphate, phosphate) at the plant's surfaces are key factors that determine the binding mechanism between the positively charged metal ions and the biomass [9]. In addition, different biologicalregulated processes such as metal uptake by transmembrane proteins and/or ionic channels, expression of metalloproteins and phytochelatins, and translocation to leaves are also part of the heavy metals' removal mechanisms used by plants [10].

Moreover, some studies with native or autochthonous freefloating macrophytes exposed to high levels of heavy metals have revealed that toxic effects to plants related to metals exposition were minimal or absent $[9,10]$. In addition, these plants were also resistant to daily-metal exposition at long term [11]. Therefore, it seems that metal-selective metabolic and/or physiological responses in some plant species could also exist, and such responses may not only be dependent on the physicochemical behavior of the metal but also on its concentration, and to a lesser extent, on the exposure time to the toxicant [10].

Phytoremediation of industrial effluents has been satisfactorily implemented both in constructed wetlands and treatment lagoons [1,4-6]. In addition, the use of plants for heavy metal remediation from aquatic environments have the additional advantage that plant biomass can be easily harvested and treated for metal recovery before its final disposal. Additionally, freefloating, and emerging plants (i.e., helophytes) are naturally distributed in several tropical and subtropical regions around the globe, thus, the implementation and management of plant-based ecotechnologies for treating metal-containing effluents seems to be a worldwide viable solution in all such environments with high yield of autochthonous plants species [9-11].

\section{References}

1. Azimi A, Azari A, Rezakazemi M, Ansarpour M (2017) Removal of heavy metals from industrial wastewaters: a review. ChemBioEng Reviews 4(1): 37-59.

2. Jaishankar M, Tseten T, Anbalagan N, Mathew BB, Beeregowda KN (2014) Toxicity, mechanism and health effects of some heavy metals. Interdisciplinary Toxicology 7: 60-72.

3. WHO (2017) Chemical Safety - Activity Report. World Health Organization, Geneva, Switzerland.

4. Ali H, Khan E, Sajad MA (2013) Phytoremediation of heavy metals concepts and applications. Chemosphere 91(7): 869-881.

5. Barakat M A (2011) New trends in removing heavy metals from industrial wastewater. Arabian Journal of Chemistry 4(4): 361-377.

6. Sukumaran D (2013) Phytoremediation of heavy metals from industrial effluent using constructed wetland Technology. Appl Ecol Environ Sci 1: 92-97.

7. Dixit R, Wasiullah E, Malaviya D, Pandiyan K, Singh UB, et al. (2015) Bioremediation of heavy metals from soil and aquatic environment: an overview of principles and criteria of fundamental processes. Sustainability 7: 2189-2212.

8. Rai PK (2009) Heavy metal phytoremediation from aquatic ecosystems with special reference to macrophytes. Critical Reviews in Environmental Science and Technology 39(9): 697-753.

9. Tello Zevallos W, Salvatierra LM, Loureiro DB, Morato J, Perez LM (2018) Evaluation of the autochthonous free-floating macrophyte Salvinia biloba Raddi for use in the phytoremediation of water contaminated. Desalation and Water Treatment 103: 282-289.

10. Emiliani J, Oyarce Llatance WG, Bergara CD, Salvatierra LM, Novo LA, et al. (2020) Variations in the phytoremediation efficiency of metalpolluted water with Salvinia biloba: prospects and toxicological impacts. Water 12: 1737.

11. Castillo Loría K, Emiliani J, Herrero MS, Bergara CD, Salvatierra LM, et al. (2019) Effect of daily exposure to Pb-contaminated water into Salvinia biloba physiology and phytoremediation performance. Aquatic Toxicology 210: 158-166.

\section{Your next submission with Juniper Publishers} will reach you the below assets

- Quality Editorial service

- Swift Peer Review

- Reprints availability

- E-prints Service

- Manuscript Podcast for convenient understanding

- Global attainment for your research

- Manuscript accessibility in different formats

( Pdf, E-pub, Full Text, Audio)

- Unceasing customer service

Track the below URL for one-step submission

https://juniperpublishers.com/online-submission.php 